\title{
Neotyphodium impacts on soil nematode communities: rhizosphere - and litter-mediated interactions
}

\author{
M. OMACINI, E.J. CHANETON and C.M. GHERSA \\ IFEVA/CONICET- Facultad de Agronomia, Universidad de Buenos Aires, Argentina \\ omacini@agro.uba.ar
}

\begin{abstract}
There is a growing recognition that endophyte effects on host plant traits may be propagated through food chains. We studied Neotyphodium occultans effects on soil nematode communities mediated by current and past patch occupancy by endophyteinfected Lolium multiflorum populations. A microcosm experiment was performed to evaluate whether abundance and diversity of nematodes at different trophic levels were affected by endophyte infection through rhizosphere-mediated or littermediated effects. We found that presence of endophyte-infected plants and their aerial litter both triggered a bottom-up trophic cascade enhancing the abundance of herbivorous and predaceous nematode taxa. Endophyte infection also increased overall nematode richness, mostly through changes induced at the highest trophic level in this soil food web. Our results suggest that fungal endophytes can modify the linkages between aboveand belowground community compartments, with potential consequences on plant patch dynamics.
\end{abstract}

Keywords: soil food webs, Lolium multiflorum, Neotyphodium occultans, plant-soil feedback, after-life effects, indirect interactions, trophic cascades

\section{Introduction}

There is a growing interest in understanding the role played by feedbacks between aboveground and belowground biota in controlling community dynamics and ecosystem processes (Bardgett et al. 1998; van der Putten et al. 2001; Wardle 2002). Plants can affect soil food webs through the resources they provide for decomposers and other root-associated organisms. Fungal endophytes may indirectly affect plant-soil feedbacks by altering the quantity and quality of plant-derived resources entering the soil through aerial and underground pathways. Reciprocal interactions between endophyte-infected grasses and soil organisms have so far received little attention (Matthews \& Clay 2001), although they might be crucial for host-plant persistence and patch dynamics (Omacini et al. 2005).

Neotyphodium endophytes elicit a range of changes in host plant tissues and interactions with above- and belowground herbivores (Cook \& Lewis 2001; Popay \& Bonos 2005), which may in turn be transmitted to higher trophic levels (Faeth \& Bultman 2002; Chaneton \& Omacini 2006). Recent studies have also shown that endophytes may affect soil ecosystem processes by altering host-plant litter quality for detritivores and the decomposition environment (Omacini et al. 2004). These effects would reflect changes in decomposer food webs through decreased microbial and/or microarthropod activity in the presence of endophyteinfected plants or their dead remains (Franzluebbers et al. 1999; Lemons et al. 2005).

In this paper we focus on Neotyphodium effects on soil nematode communities as mediated by current and past patch occupancy by endophyte-infected plants, looking at the response of nematodes at different trophic levels within a mixed trophic system (rootand detritus-based energy channels). We manipulated endophyte infection levels in Lolium multiflorum populations and the origin of grass litter to test for effects of the endophyte-grass symbiosis on nematode abundance and diversity through the living host plant (rhizosphere-mediated effects) and/or the remains of prior patch occupants (litter-mediated effects). In addition, soil moisture conditions were experimentally varied to determine whether nematode responses depend upon environmental conditions.

\section{Material and Methods}

The experiment comprised L. multiflorum plants from the same parental population, whose seeds were infected or uninfected with the endophyte Neotyphodium occultans (SI treatment). Plants were grown in greenhouse microcosms subjected to conditions created by the quality of litter deposited above ground (QL) and the watering regime (WA). L. multiflorum seeds naturally infected with the endophyte $N$. occultans $(+\mathrm{SI})$ were collected from pampean oldfield communities (Buenos Aires, Argentina) dominated by this exotic species. Some of the seeds was treated with the fungicide triadimenol $(5 \mathrm{mg}$ active ingredient per $g$ seed) to kill the endophyte and obtain uninfected seeds (-SI). Both groups of seeds were sown under common environmental conditions (outdoor plots) during 2 consecutive years. Seeds and litter produced by the $\mathrm{F}_{2}$ generation were used in the present experiment. Infection levels were $98 \%$ and $9 \%$ for + SI and -SI seeds, respectively. Litter was harvested at the end of the summer, air-dried and stored until the beginning of the experiment ( $\approx 40$ days).

On 31 May, ten microcosms (50 x $50 \mathrm{~cm}, 15 \mathrm{~cm}$ deep) were arranged in five blocks in a greenhouse (10-20 ${ }^{\circ} \mathrm{C}$, night-day). Each microcosm was filled with soil obtained from a remnant pampa grassland dominated by native tussock grasses ( $L$. multiflorum absent). The original soil fauna was left intact. Each microcosm was randomly assigned to one of two watering treatments (WA: low, high). Within each microcosm, two $16 \mathrm{x}$ $34 \mathrm{~cm}$ areas were selected and were covered with litter produced by a prior generation of endophyte-infected or uninfected $L$. multiflorum plants (+QL or $-\mathrm{QL}$ respectively). On 16 June, 100 -SI and $100+$ SI were added below the litter layer in two different subplots $(10 \times 10 \mathrm{~cm})$ within each area. Two contrasting moisture regimes were applied by regularly watering the microcosms to field capacity $(\approx 3000 \mathrm{ml})$ through the litter layer and allowing them to drain freely until the soil volumetric water content reached $70 \%$ (WA-high: watered once a week) or $40 \%$ of field capacity (WA-low: watered every third week). During the experiment, moisture levels were significantly affected by watering regime (Omacini et al. 2004).

On 20 August, two $6 \mathrm{~cm}$-deep by $5 \mathrm{~cm}$-diameter soil cores were collected from the root zone in each subplot to determine nematode abundances. Nematodes were extracted from a bulk sample ( $20 \mathrm{~g})$ of the two soil cores using the centrifugation technique (Shurtleff $\&$ Averre 2000). Nematodes were determined to genus or family level using an inverted light microscope, and were further assigned to six feeding guilds occupying four different trophic levels (Wardle et al. 2003). Trophic levels (with feeding guilds in brackets) included herbivores (plant feeders including migratory root parasites), microbivores (bacterial and fungal feeders), predators and top predators (saprophagous and omnivores). The ratio of bacterial-feeding to fungal-feeding nematode abundance 
was calculated as an indicator of the relative importance of the bacterial and fungal energy channels in the different treatments (Wardle et al. 2003). Plants were harvested and weighed after oven-drying at $80^{\circ} \mathrm{C}$ for $48 \mathrm{~h}$.

Total nematode numbers and abundance within each trophic level were analysed using analysis of covariance (ANCOVA) for a split-plot design with blocks, including watering regime (WA) as main plot factor, litter quality (QL) and seed infection (SI) level as sub-plot factors and plant biomass per subplot as covariate. These analyses revealed no significant effects of the biomass covariate; therefore, results for a split-plot ANOVA are shown here. Nematode species richness was also analysed using similar ANCOVA models but including the corresponding nematode abundances as covariates to adjust for "rarefaction" effects.

\section{Results}

Total nematode numbers did not differ between soils beneath infected and uninfected plants but was significantly influenced by the interaction between litter quality and watering regime (Fig. 1, Table 1). Nematode abundance was higher in + QL than in $-Q L$ microcosms under WA-high conditions (Table 1). Microbivores were not affected by endophyte treatments. Herbivores were slightly more abundant in the treatments including endophyte infected plants and litter produced by infected plants than in those with uninfected plants and their litter (Fig. 1, Table 1). In addition, endophyte increased the abundance of top predators, the most abundant group (Fig. 2), through conditions created by both infected host plants (+SI) and the litter produced by infected plants $(+\mathrm{QL})$ in WA-high microcosms (Table 1). The ratio of

Table 1 Split-plot analysis of variance (ANOVA) testing the effects of watering regime (WA), litter quality (QL), and infection level of living plants $(\mathrm{SI})$ on nematode abundances and the ratio of bacterial- to fungal-feeding nematodes (B/F). Numbers shown are F values.

\begin{tabular}{lcrccccc}
\hline & df & Total & Microbivores & Herbivores & Predators & Top-predators & B/F \\
\hline Block & 4 & 40.6 & 3.7 & 1.6 & 5.9 & 26.7 & 3.1 \\
Watering regime (WA) & 1 & 1.1 & 0.2 & 2.9 & 1.4 & 1.4 & 0.6 \\
Error a & 4 & & & & & & \\
Litter quality (QL) & 1 & 1.7 & 1.0 & 0.2 & 0.0 & 3.3 & 0.1 \\
Plant infection (SI) & 1 & 2.0 & 0.5 & 2.5 & 2.6 & 0.0 & 1.5 \\
$\mathrm{WA}^{*} \mathrm{QL}$ & 1 & $8.9^{* \star}$ & 0.0 & 1.6 & 0.0 & $9.5^{\star * *}$ & 0.9 \\
$\mathrm{WA}^{*} \mathrm{SI}$ & 1 & 3.1 & 0.5 & 0.2 & 0.1 & $5.5^{\star *}$ & 2.4 \\
$\mathrm{QL}^{*} \mathrm{SI}$ & 1 & 1.5 & 0.0 & $4.6^{*}$ & 0.8 & 0.0 & 0.1 \\
$\mathrm{WA}^{*} \mathrm{SI}{ }^{*} \mathrm{QL}$ & 1 & 0.2 & 2.7 & 0.9 & 0.2 & 0.1 & 0 \\
Error b & 24 & & & & & & \\
\hline
\end{tabular}

${ }^{\star} \mathrm{P} \leq 0.05,{ }^{\star *} \mathrm{P} \leq 0.01,{ }^{\star \star *} \mathrm{P} \leq 0.005$

Table 2 Split-plot analysis of covariance (ANCOVA) testing the effects of watering regime (WA), litter quality (QL), and infection level of living plants (SI) on nematode species richness, including the corresponding nematode abundances as covariates. Numbers shown are F values.

\begin{tabular}{lcccccc}
\hline & df & Total & Microbivores & Herbivores & Predators & Top-predators \\
\hline Block & 4 & 13.2 & 1.7 & 1.1 & 1.1 & 5.6 \\
Watering regime (WA) & 1 & 0.2 & 0.1 & 0.1 & 0.1 & 0.3 \\
Error a & 4 & & & & & \\
Litter quality (QL) & 1 & 0.3 & 0.0 & 0.6 & 1.9 & 0.1 \\
Plant infection (SI) & 1 & 1.2 & 0.5 & 0.1 & 0.2 & 2.5 \\
WA * QL & 1 & 1.3 & 1.1 & 0.2 & 1.4 & 0.0 \\
WA * SI & 1 & 1.2 & 0.1 & 0.0 & 1.0 & 4.4 \\
QL * SI & 1 & 0.1 & 0.3 & 0.2 & 0.3 & 1.6 \\
WA * SI * QL & 1 & 0.5 & 0.2 & 0.1 & 1.4 & 0.0 \\
Nematode abundance & 1 & $12.7^{* \star *}$ & $4.3^{*}$ & $9.5^{* *}$ & $45.0^{* * *}$ & $9.7^{* \star}$ \\
Error b & 23 & & & & & \\
\hline
\end{tabular}

${ }^{*} \mathrm{P} \leq 0.05,{ }^{* \star} \mathrm{P} \leq 0.01,{ }^{* \star *} \mathrm{P} \leq 0.005$ 
Figure 1 Changes in nematode abundances (mean \pm standard error) as affected by infection level of living plants (SI), quality of litter cover (QL) and watering regime (WA). Nematodes predators were not included because of the low density through the experiment (range 3-11 individuals per $100 \mathrm{~g}$ soil).
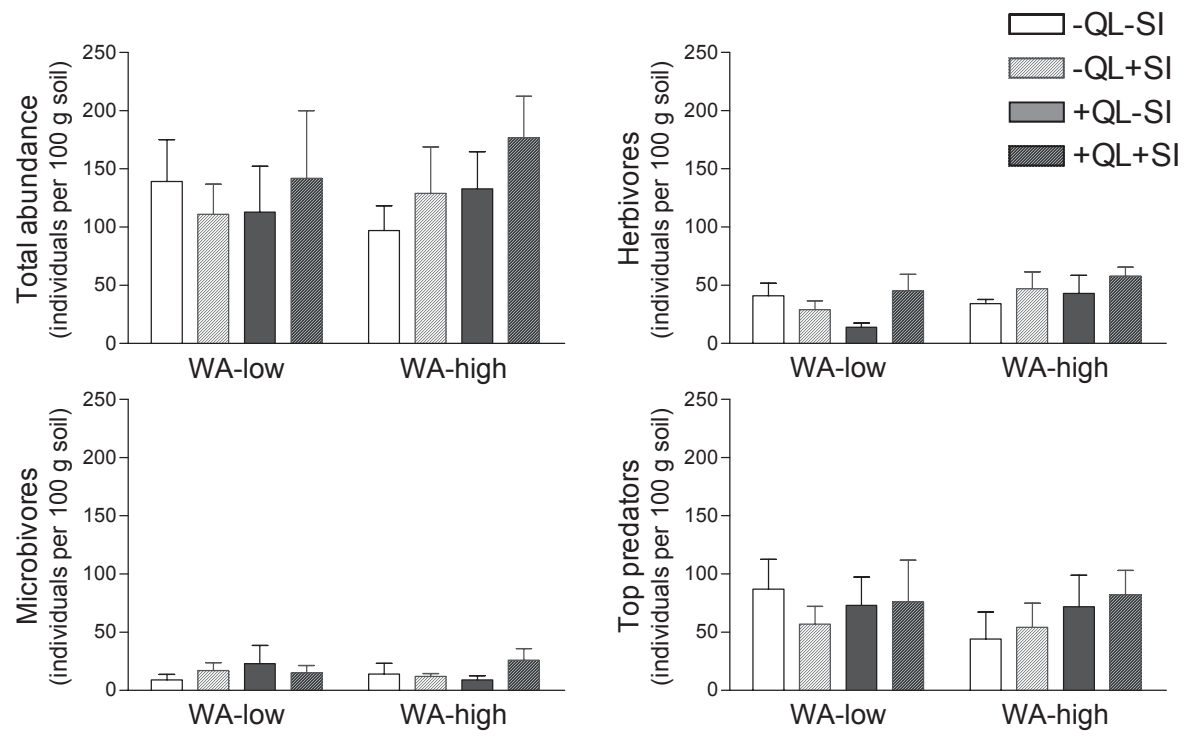

Figure 2 Changes in nematode species richness (mean \pm standard error) as affected by infection level of the living plants (IS) and watering regime (WA). Data were pooled for the litter (QL) factor (see Table 2 for full statistics).
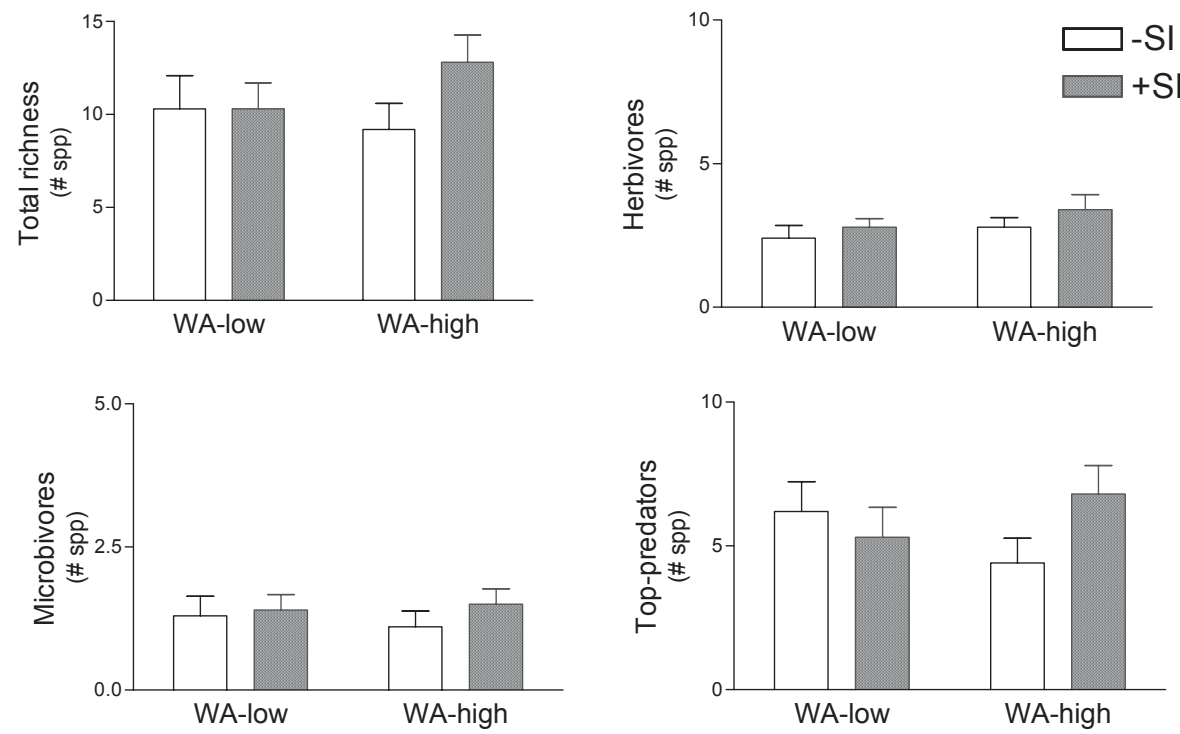

bacterial- to fungal-feeding nematodes was highly variable (range 0-3.4) and did not differ across treatments (Table 1).

Nematodes species richness was significantly affected by the watering regime and plant infection level (ANOVA, watering regime effect WA: $\mathrm{F}_{1,24}=13.4, \mathrm{P}=0.02$ and plant infection effect SI: $\mathrm{F}_{1,24}=4.9, \mathrm{P}=0.036$; Fig. 2). Higher richness was observed in + SI soil compared to -SI soil, regardless of the type of litter cover (litter quality effect QL and QL*SI interaction were not

significant). This endophyte effect was due to the increased number of top-predator species in +SI and WA-high treatments (WA*SI: $F_{1,24}=7.3, P=0.012$ ) (Table 2). With the exception of top predators, effects on richness were explained by differences in total nematode abundance among treatments (Table 2, abundance covariate for each variable). Richness of microbivores, herbivores and predators were not influenced by the experimental factors (Fig. 2, Table 2). 


\section{Discussion}

Recent studies recognised that fungal endophytes can modify the structure and function of plant and arthropod communities (e.g. Clay \& Holah 1999; Omacini et al. 2001, 2004; Lemons et al. 2005; Finkes et al. 2006). Here, we showed that Neotyphodium occultans in L. multiflorum increased the abundance and richness of soil invertebrate consumers, in particular of predaceous nematodes in frequently watered microcosms, even though watering regime did not affect litter decomposition rates (Omacini et al. 2004). Although we are unable to define the underlying causal mechanisms, current and past patch occupancy by endophyte-infected annual plants modified the structure of soil nematode communities (rhizosphereand litter-mediated effects) under certain conditions. It is inferred that endophytes caused changes in microenvironmental conditions and soil ecosystem function, as high-trophic levels were promoted (Wardle et al. 2003).

Endophyte effects on host plant productivity and quality have been shown to propagate through both above- and below-ground food chains (see Chaneton \& Omacini 2006, for a review). Our results suggest that endophytes can elicit bottom-up cascades in soil webs, which are transmitted to upper trophic levels through a trait modification of the host plant living and dead tissues. Endophyte effects were more apparent for top predators than for intermediate consumers including herbivorous and microbivorous nematodes. As top predaceous nematodes are assumed to play a regulating role both in the soil food web and in buffering outbreaks of soil-borne plant diseases (Bongers \& Ferris 1999), top-down cascades might attenuate endophyte effects on herbivores and microbivores.

Contrary to our expectations, we detected an increase in the number of herbivorous nematodes mediated by living-plant infection and their litter. Previous studies showed that endophyte infection in tall fescue and perennial ryegrass can reduce the number of individuals of various genera included in this trophic group (e.g. Pratylenchus, Helicotylenchus, see review Cook $\&$ Lewis 2001). Therefore, we cannot discard the possibility of an indirect endophyte effect on nematode interactions with microorganisms or arthropods that has generated an increase in herbivore or top-predator nematodes. Nevertheless, several issues still need be addressed to enhance our current understanding of the role of endophytes in multitrophic interactions.

In conclusion, grass endophytes may operate as drivers of soil food webs without changes in aboveground plant species composition. Our previous work (Omacini et al. 2001, 2004) and these new findings have implications for understanding how the widespread $N$. occultans-L. multiflorum symbiosis can modify ecosystem functioning, including the reciprocal interactions between plants and soil biota.

\section{ACKNOWLEDGEMENTS}

We thank Isabel Miranda, Rosario Balve and Juana Roset for field assistance. This work was supported by grants from Sigma Xi Society, Agencia Nacional de Promoción Científica y Tecnológica (FONCYT) of Argentina, and Fundación Antorchas.

\section{REFERENCES}

Bardgett, R.; Wardle, D.; Yeates, G. 1998. Linking aboveground and below-ground interactions: how plant responses to foliar herbivory influence soil organisms. Soil Biology and Biochemistry 14: 1867-1978.

Bongers, M.; Ferris, H. 1999. Nematode community structure as a bioindicator in environmental monitoring. Trends in Ecology and Evolution 14: 224-228.

Chaneton, E.; Omacini, M. 2006. Bottom-up cascades induced by fungal endophytes in multitrophic systems (in press). In: Ecological communities: plant mediation in indirect interaction webs. Eds. Ohgushi, T.; Craig, T.P.; Price, P.W. Cambridge University Press, Cambridge.

Clay, K.; Holah, J. 1999. Fungal endophyte symbiosis and plant diversity in successional fields. Science 285: 1742-1744.

Cook, R.; Lewis, G.C. 2001. Fungal endophytes and nematodes of agricultural and amenity grasses, pp. 35-61. In: Biotic Interactions in plant-pathogen associations. Eds. Jeger, M.J.; Spence, N.J.

Faeth, S. H.; Bultman, T.L. 2002. Endophytic fungi and interactions among host plants, herbivores, and natural enemies. pp 89123 In: Multitrophic Level Interactions. Eds. Tscharnkte, T; Hawkins, B.A. Cambridge Univ. Press, Cambridge.

Finkes, L.; Cady, A.; Mulroy, J.; Clay, K.; Rudgers, J. 2006. Plantfungus mutualism affects spider composition in successional fields. Ecology Letters 9: 347-356.

Franzluebbers, A.J.; Nazih, N.; Stuedemann, J.A.; Fuhrmann, J.J.; Shomberg, H.H.; Hartel, P.G. 1999. Soil carbon and nitrogen pools under low- and high-endophyte-infected tall fescue. Soil Science Society of America Journal 63: 1687-1694.

Kunkel, B.; Grewal, P. 2003. Endophyte infection in perennial ryegrass reduces the susceptibility of black cutworm to an entomopathogenic nematode. Entomologia Experimentalis et applicata 107: 95-104.

Lemons, A.; Clay, K.; Rudgers, J.A. 2005. Connecting plantmicrobial interactions above and belowground: a fungal endophyte affects decomposition. Oecologia.145: 595-604.

Matthews, J.W.; Clay, K. 2001. Influence of fungal endophyte infection on plant/soil feedback and community interactions. Ecology 82: 500-509.

Omacini, M.; Chaneton, E.J.; Ghersa, C.M.; Muller, C.B. 2001. Symbiotic fungal endophytes control insect host-parasite interaction webs. Nature 409: 78-81.

Omacini, M.; Chaneton, E.; Ghersa, C.M.; Otero, P. 2004. Do foliar endophytes affect grass litter decomposition? A microcosm approach using Lolium multiflorum. Oikos 104: 581-590.

Omacini, M.; Chaneton, E.J.; Ghersa, C.M. 2005. A framework for understanding the ecosystem consequences of endophyte grass symbioses. pp. 141-161. In: Neotyphodium in CoolSeason Grasses Current Research \& Applications. Eds. Roberts, C.; West, C.P.; Spiers, D. Blackwell Publishing.

Popay, A.I.; Bonos, S.A. 2005. Biotic responses in endophytic grasses. pp. 163-185. In: Neotyphodium in Cool-Season Grasses Current Research \& Applications. Eds. Roberts, C., West, C.P; Spiers, D, Blackwell Publishing.

Shurtleff M.C.; Averre III, C.W. 2000. Diagnosing plant disease caused by nematodes. APS Press, Minnesota. 187 pp.

van der Putten, W.H.; Vet, L.E.M.; Harvey, J.H.; Wackers, F.L. 2001. Linking above and belowground multitrophic interactions of plants, herbivores, pathogens, and their antagonists. Trends in Ecology \& Evolution 16: 547-554.

Wardle, D. 2002. Communities and Ecosystems: Linking the Aboveground and Belowground Components. Princeton University press. $400 \mathrm{pp}$.

Wardle, D.A.; Yeates, G.W.; Williamson, W.; Bonner, K.I. 2003. The response of a three trophic level soil food web to the identity and diversity of plant species and functional groups. Oikos 102: 45-56. 